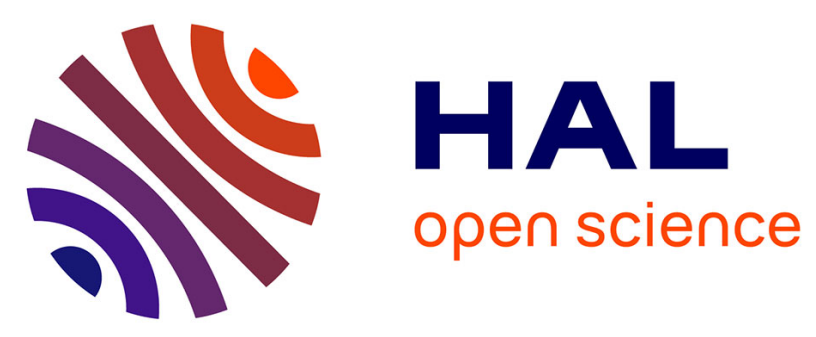

\title{
Thermal Stress in Melon Plants: Phytoprostanes and Phytofurans as Oxidative Stress Biomarkers and the Effect of Antioxidant Supplementation
}

Melisa Yonny, Ariel Rodríguez Torresi, Claire Cuyamendous, Guillaume Reversat, Camille Oger, Jean-Marie Galano, Thierry Durand, Claire Vigor,

Mónica Nazareno

\section{To cite this version:}

Melisa Yonny, Ariel Rodríguez Torresi, Claire Cuyamendous, Guillaume Reversat, Camille Oger, et al.. Thermal Stress in Melon Plants: Phytoprostanes and Phytofurans as Oxidative Stress Biomarkers and the Effect of Antioxidant Supplementation. Journal of Agricultural and Food Chemistry, 2016, 64 (44), pp.8296-8304. 10.1021/acs.jafc.6b03011 . hal-02612433

\section{HAL Id: hal-02612433 \\ https://hal.science/hal-02612433}

Submitted on 2 Jun 2021

HAL is a multi-disciplinary open access archive for the deposit and dissemination of scientific research documents, whether they are published or not. The documents may come from teaching and research institutions in France or abroad, or from public or private research centers.
L'archive ouverte pluridisciplinaire $\mathbf{H A L}$, est destinée au dépôt et à la diffusion de documents scientifiques de niveau recherche, publiés ou non, émanant des établissements d'enseignement et de recherche français ou étrangers, des laboratoires publics ou privés. 


\title{
Thermal Stress in Melon Plants: Phytoprostanes and Phytofurans as Oxidative Stress Biomarkers and the Effect of Antioxidant Supplementation
}

\author{
Melisa E. Yonny, ${ }^{\dagger}$ Ariel Rodríguez Torresi, ${ }^{\ddagger}$ Claire Cuyamendous, ${ }^{\S}$ Guillaume Réversat, ${ }^{\S}$ Camille Oger, $^{\S}$ \\ Jean-Marie Galano, ${ }^{\S}$ Thierry Durand, ${ }^{\S}$ Claire Vigor, ${ }^{*} \S$ and Mónica A. Nazareno ${ }^{* \dagger}$ \\ ${ }^{\dagger}$ CITSE-CONICET, Universidad Nacional de Santiago del Estero, RN 9 Km 1125, Villa El Zanjón, C.P. 4206, Santiago del Estero, \\ Argentina \\ ${ }^{\ddagger}$ INTA Santiago del Estero, C.P. 4200, Santiago del Estero, Argentina \\ ${ }^{\S}$ Institut des Biomolécules Max Mousseron (IBMM), UMR 5247, CNRS, University of Montpellier, ENSCM, F-34093 Montpellier, \\ France
}

\begin{abstract}
The extreme temperatures generated in the melon crop, early harvest, induce an increase in reactive oxygen species (ROS) plant levels leading to oxidative stress. Phytoprostanes (PhytoPs) and phytofurans (PhytoFs) are plant metabolites derived from $\alpha$-linolenic acid oxidation induced by ROS. The aims of this work were to evaluate PhytoPs and PhytoFs as oxidative stress biomarkers in leaves of melon plants thermally stressed. In addition, to fortify melon plant antioxidant defenses, foliar spraying was assayed using salicylic and gallic acid solutions and Ilex paraguariensis extract. PhytoP and PhytoF concentration ranges were 109-1146 and 130-4400 ng/g, respectively. Their levels in stressed plants were significantly higher than in nonstressed samples. In stressed samples treated with I. paraguariensis, PhytoP and PhytoF levels were significantly lower than in stressed samples without antioxidants. PhytoPs and PhytoFs represent relevant oxidative stress biomarkers in melon leaves. The use of natural antioxidants could reduce plant oxidative stress.
\end{abstract}

KEYWORDS: melon leaves, lipid oxidation, phytoprostanes, phytofurans, antioxidants foliar spraying, biomarkers

\section{INTRODUCTION}

Nowadays, the agricultural challenge is to maintain a high level of productivity and quality to ensure sufficient food supply. ${ }^{1}$ The effects of climate change should be mitigated because they are the main factors of abiotic stress that affect crop yields in arid and semiarid regions. ${ }^{2}$ Abiotic stress arises when a cell or a whole plant is exposed to unfavorable environmental conditions such as water deficit, salinity, extreme temperatures, and excessive light; reductions of $>50 \%$ in plant growth have been reported in most species under stress. ${ }^{3}$ Abiotic stress leads to the activation of reactive oxygen species (ROS) in the plant physiology and, thus, to oxidative stress. ${ }^{4}$ The melon (Cucumis melo L.) is a warm-season annual crop. It is very sensitive to air temperature and does not tolerate frosts at any time of its growth. This seasonality of melon production was modified using early-harvest systems in areas where the conditions during the winter are tempered. These mild winter conditions give to melons the opportunity of entering into the fruit market when supply is scarce and, hence, fruits are sold with differential prices. This production is carried out using micro- and macrostructured tunnels covered by different types of materials, especially plastics. Under these conditions, extreme temperatures (high or low ones) induce abiotic stress in plants and increase ROS production, affecting the photosynthetic apparatus. $^{5,6}$ Excess ROS can be deleterious to different biomolecules, unsaturated lipids being the most susceptible to ROS attack, leading to the lipid oxidation reaction. ${ }^{7}$ Indeed, the structural occurrence of multiple double bonds, and especially in bis-allylic position with highly reactive hydrogen, allows the generation of oxygenated metabolites in the presence of free radicals.

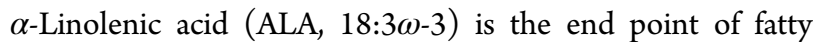
acid biosynthesis in higher plants, and it can be a very reactive substrate in lipid oxidation reactions initiated by ROS, causing prostaglandin/jasmonate-like compounds called phytoprostanes (PhytoPs). Its oxidation reaction produces two series of regioisomeric PhytoPs, the 9- and 16-series consisting of 16 stereoisomers. ${ }^{7}$ The possible structures are $\mathrm{F}_{1^{-}}, \mathrm{D}_{1^{-}}, \mathrm{E}_{1^{-}}, \mathrm{A}_{1^{-}}$, deoxy- $\mathrm{J}_{1^{-}}, \mathrm{B}_{1^{-}}$, and $\mathrm{L}_{1}$-PhytoPs. ${ }^{8}$ Basal levels of PhytoPs were found in various plant matrices such as different parts of herbs, ${ }^{9}$ algae, ${ }^{10}$ beverages, ${ }^{11,12}$ and nuts. ${ }^{13}$ Moreover, particularly in almonds, the quantitative changes in PhytoPs were monitored as markers to detect the undesirable oxidation processes caused by their processing and storage conditions. ${ }^{14}$ Finally, the PhytoP level in fruits of mature olive trees after their exposure to water deficit was also evaluated, and it increased 1.7 times when the plants were exposed to stress conditions. ${ }^{15}$ Under high oxygen tension, a novel structure of compounds was uncovered, which follows the same free radical pathway of PhytoPs. The addition of molecular oxygen after initial cyclization leads to the generation of furanic structures named phytofurans (PhytoFs). ${ }^{16,17}$ These were recently identified and quantified in seeds and nuts. ${ }^{17}$ 
The development of methods to induce stress tolerance in plant is a topic of interest. Numerous approaches are considered, such as spraying of crop protection agents. In 2012, Ghobadi's team proposed the use of salicylic acid (SA) to enhance banana plant tolerance against water stress. SA application improved plant shoot tips by increasing proliferation rate, fresh weight increase, and relative water content under stress conditions. SA treatments enhanced plant tolerance against oxidative stress evidenced through the significant reduction in the content of malondialdehyde (MDA) as an oxidative stress biomarker. ${ }^{18}$ This agrees with the literature, which highlights the SA role in increasing the activity of antioxidant enzymes such as superoxide dismutase (SOD). ${ }^{19}$ More recently, a study involving the exogenous application of SA in sweet pepper plants prior to their exposure to salinity stress corroborated this result. The activation of antioxidant enzymes in respect to control was also observed in this case. ${ }^{20}$ Gallic acid (GA) is another phenolic compound that has in vitro antioxidant properties. ${ }^{21}$ It has been reported that GA application in rice cultivars mitigated the effects of osmotic and salt stress in these plants and resulted in decreasing MDA content and increasing catalase, peroxidase, or SOD activities, as SA application does. ${ }^{22}$

Ilex paraguariensis A. St-Hil. (Aquifoliaceae), popularly known as yerba mate (YM), is a native plant from the subtropical region of South America, where it is widely consumed. It has become popular in the United States in the past few years. ${ }^{23}$ Previous research has identified and quantified different phenolic compounds in YM such as chlorogenic acid and its derivatives (3,4-di-O-dicaffeoylquinic, 3,5-di-O-dicaffeoylquinic, and 4,5-di-O-dicaffeoylquinic acids) and caffeic acid as well as flavonoids such as quercetin, rutin, and kaempfer$\mathrm{ol}^{24-26}$ It has been reported that these compounds have antioxidant, anti-inflammatory, immunomodulatory, and anticancer effects. $^{23,27}$ In these senses, evidence of the antioxidant effect has been found with the addition of YM extract to some food products such as chicken meat ${ }^{28}$ and sausages. ${ }^{29,30}$ Taking into account this activity, we propose herein that the polyphenolic compounds from the aqueous extract of I. paraguariensis can reduce the oxidative stress levels of melon plants exposed to thermal stress during the early production of this crop. The main aim of the present study was to evaluate the effect of foliar spraying with solutions of SA or GA and with a YM extract on melon plants during their cultivation under thermal stress to fortify their antioxidant defense system. To the best of our knowledge, this is the first time that a foliar application of the YM extract is assayed as a natural antioxidant source. The oxidative stress in the melon plants was evaluated by monitoring PhytoP and PhytoF levels by micro-HPLC coupled to a QTRAP detector (triple-quadrupole mass spectrometer combined with a lineal ion trap). Liquid chromatography coupled to mass spectrometry detection is the most common analytical technique used to quantify the isoprostanoide compounds derived from polyunsaturated fatty acid oxidation. ${ }^{31}$ PhytoPs have been quantified in previous studies as oxidative stress biomarkers; ${ }^{14,15}$ however, PhytoFs are measured for the first time in the present study in a plant system after its exposure to stressful condition. With respect to the plant material, PhytoP and PhytoF levels are determined at the first time in leaves of melon plants. For this, the analytical parameters involved in the quantification process were also evaluated.

\section{MATERIALS AND METHODS}

Chemicals and Reagents. Analytical standards of PhytoPs and PhytoFs were synthesized according to our previous procedures, ${ }^{17,32-34}$ and they were used as analytical standards. The compound 15-epi-15- $\mathrm{F}_{2 \mathrm{t}}$-IsoP-C21 was used as internal standard and was synthesized in the laboratory with similar procedures as already mentioned. $^{32-34}$ It is important to note that besides the fact that PhytoP and PhytoF deuterated standards are not commercially available, the 15-epi-15- $\mathrm{F}_{2 \mathrm{t}}$-IsoP-C21 was also selected as internal standard because its structure is close to that of the natural products and because it does not occur in nature. PhytoP and PhytoF stock solutions in methanol were prepared to a concentration of $100 \mathrm{ng}$ $\mu \mathrm{L}^{-1}$ and were stored at $-20{ }^{\circ} \mathrm{C}$. Appropriate dilutions from the mentioned stock were prepared for calibration purposes. SA and GA were purchased from Sigma-Aldrich (Buenos Aires, Argentina). LCMS water, methanol, acetonitrile, and chloroform were obtained from Fisher Scientific (Loughborough, UK); CHROMASOLV, for HPLC, $\geq 99.7 \%$ hexane, and formic acid (Fluka) for mass spectrometry (98\%) were provided by Sigma-Aldrich (St. Louis, MO, USA). Solid phase extraction cartridges (SPE) Oasis MAX with mixed polymer phase were purchased ( $3 \mathrm{~mL}, 60 \mathrm{mg}$ ) from Waters (Milford, MA, USA). Milli-Q ultrapure water was used to prepare all of the aqueous solutions.

Plant Samples and Crop Management. Seeds of melon plants of the Sweet Ball cultivar (cv.) and Early Spring cv. were provided by Rijkzwaan (Buenos Aires, Argentina). The seeds were sown in a vivarium and were used in two different assays: assay 1 (Sweet Ball cv.) and assay 2 (Early Spring cv.). When the plants had two true leaves, they were transplanted in rows spaced at $1.70 \mathrm{~m}$ and with a distance between plants of $0.70 \mathrm{~m}$, representing a plant density of 12,100 plants $\mathrm{ha}^{-1}$. The soil characterization indicated that it contained $0.06 \% \mathrm{~N}, 64$ ppm of $\mathrm{P}, 94 \mathrm{mg} \mathrm{L}^{-1} \mathrm{~K}$, and $86 \mathrm{mg} \mathrm{L}^{-1} \mathrm{Ca}, \mathrm{pH} 7.3$, and the electric conductivity (EC) was $1.20 \mathrm{dSm}^{-1}$. The irrigation system used was localized and complementary to rainfall, being that $126 \mathrm{~mm}$ was contributed by dripping. One-tape irrigation was placed in each plant row. Droppers were placed every $20 \mathrm{~cm}$ on the tape irrigation, and each dropper yields a rate of $0.8 \mathrm{~L} \mathrm{~h}^{-1}$. Preventive phytosanitary control was performed using four products based on dithiocarbamates, neonicotinoid, avermectin, and organophosphate.

Preparation of Spray Solutions. Antioxidant solutions of GA and SA were prepared at $0.2 \%(\mathrm{w} / \mathrm{v})$ in water. The I. paraguariensis or YM ground dried leaves were acquired at a local supermarket. The extract was prepared by decoction; its concentration was $20 \mathrm{~g} \mathrm{YM} \mathrm{L}^{-1}$, and it was boiled for $40 \mathrm{~min}^{35}$ and then allowed to reach room temperature and filtered through a colander. Antiradical activity against 1,1-diphenyl-2-picrylhydrazyl radical $\left(\mathrm{DPPH}^{\circ}\right)$ of the mentioned YM extract was equivalent to $40 \mathrm{~g} \mathrm{GA} \mathrm{L}^{-1}$. GA and SA solutions and YM extract were applied to the melon plant leaves by spraying 25 plants per liter $(40 \mathrm{~mL} / \mathrm{plant})$ with a hand sprayer.

Treatments. Each assay (1 and 2) corresponded to 36 plants, and these were divided into two groups, one of them being constituted by 18 plants covered with plastic of $30 \mu \mathrm{m}$ thickness at the 15 th day after transplantation for 5 days; in the remaining one, 18 plants were kept uncovered during the whole experiment. Each group was divided into three subgroups, one for control and two for antioxidant application. The experimental design was completely randomized with six plants for each treatment as shown in Figure 1.

Antioxidant solutions were added to plants by foliar spraying at the 10 th and 15th days after transplantation. In assay 1 , SA solution or the YM extract was used to spray two groups (stressed and nonstressed) of 6 plants, whereas in assay 2, GA solution or the YM extract was sprayed to the mentioned stressed and nonstressed sample groups. Control groups of assays 1 and 2 were sprayed with water.

Plants covered with plastic were exposed to temperatures between 35 and $45{ }^{\circ} \mathrm{C}$. Meanwhile, the environmental temperature range registered was $25-30{ }^{\circ} \mathrm{C}$ during the mentioned 5 days. Leaves from melon plants were harvested at the 20th day after transplantation. Fresh leaves were lyophilized for $72 \mathrm{~h}$ at $-80{ }^{\circ} \mathrm{C}$ and $5 \mu$ Torr. The dried samples were stored at $-20{ }^{\circ} \mathrm{C}$ until their analysis. 


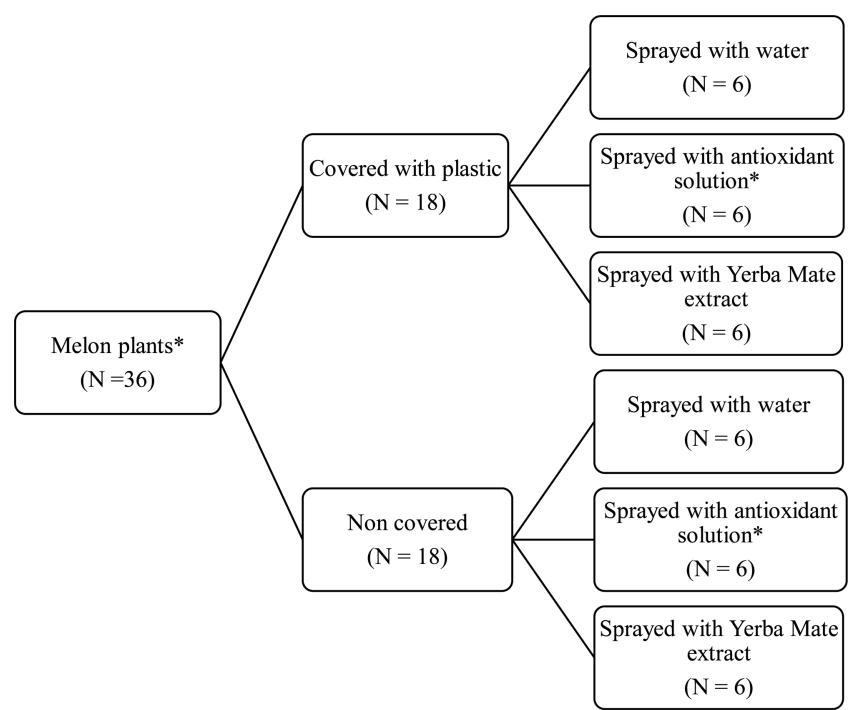

* Assay 1 (Sweet ball cv.): antioxidant spraying with salicylic acid or Assay 2: (Early spring cv.): antioxidant spraying with gallic acid

Figure 1. Treatment distribution scheme for PhytoP and PhytoF analysis in leaves of melon plants of each assay (1 and 2). More details of the treatments depicted here are described in the text.

Liquid Chromatography and Mass Spectrometry Conditions. An Eksigent (Sciex Applied Biosystems, Framingham, MA, USA) micro-HPLC equipped with CTC Analytics AG (Zwingen, Switzerland) was used. The autosampler vial tray was kept at $10^{\circ} \mathrm{C}$. The needle was washed with proper mixtures of acetonitrile/water/ isopropanol $(1: 1: 1 ; \mathrm{v} / \mathrm{v})$ and then with water. The separation was performed by injecting a $5 \mu \mathrm{L}$ sample volume onto an HALO $\mathrm{C}_{18}$ (Sciex Applied Biosystems) analytical column with a $0.5 \mu \mathrm{m}$ shell of porous silica, a $100 \mathrm{~mm}$ length, and a $2.7 \mu \mathrm{m}$ particle size. The mobile phases consisted of a binary gradient of (A) water with $0.1 \%(\mathrm{v} / \mathrm{v})$ of formic acid and (B) acetonitrile with $0.1 \%(\mathrm{v} / \mathrm{v})$ of formic acid delivered at $0.03 \mathrm{~mL} \mathrm{~min}^{-1}$. The elution was in gradient mode starting with $17 \%$ solvent B, increasing to $34 \%$ solvent B at $15 \mathrm{~min}$ and $90 \%$ solvent $\mathrm{B}$ at $15.2 \mathrm{~min}$, and then returned to the initial conditions at $18.2 \mathrm{~min}$. The column was held at $40^{\circ} \mathrm{C}$. Under these conditions, no sample contamination or sample-to-sample carry-over was observed.

Mass spectrometry analyses were performed on an AB SCIEX QTRAP 5500 (Sciex Applied Biosystems). The ionization source was electrospray (ESI), and it was operated in the negative mode. The source voltage was kept at $-4.5 \mathrm{kV}$, and $\mathrm{N}_{2}$ was used as curtain gas. Detection of the fragmentation ion products from each PhytoP or PhytoF deprotonated molecule $[\mathrm{M}-\mathrm{H}]^{-}$was performed in the multiple reaction monitoring mode (MRM). Quantification of PhytoPs and PhytoFs was done by measuring the area under the specific peak using MultiQuant 3.0 software (Sciex Applied Biosystems).

Sample Pretreatment. PhytoP and PhytoF extraction of plant tissues was carried out as suggested by Leung et al. ${ }^{36}$ Some minor changes were included in the mentioned methodology to adapt it to the study of a plant system. Thus, dried leaves were reduced to powder using a Kenwood AT320A electric mincer and, initially, different amounts of samples were assayed. The optimized sample pretreatment was as follows: $0.20 \mathrm{~g}$ of sample in powder was taken, and an aliquot of $2.0 \mathrm{~mL}$ of $0.1 \%(\mathrm{w} / \mathrm{v})$ butylated hydroxytoluene (BHT) in methanol was added. This mixture was stirred at $1300 \mathrm{rpm}$ for $30 \mathrm{~min}$. Then, the methanol extract was centrifuged at $4000 \mathrm{rpm}$ for $10 \mathrm{~min}$ at $25^{\circ} \mathrm{C}$. The supernatant was separated, and $1.0 \mathrm{~mL}$ of water and $4.0 \mathrm{~mL}$ of chloroform were added. This mixture was stirred at $1300 \mathrm{rpm}$ for 15 $\mathrm{min}$. Subsequently, the emulsion was centrifuged at $4000 \mathrm{rpm}$ for 10 min at $25{ }^{\circ} \mathrm{C}$. The chloroform phase was separated and concentrated with $\mathrm{N}_{2}$ at $40{ }^{\circ} \mathrm{C}$. Then, aliquots of $1 \mathrm{~mL}$ of $1 \mathrm{M} \mathrm{KOH}$ and $2 \mathrm{~mL}$ of $0.04 \mathrm{M}$ formic acid, $\mathrm{pH} 4.5$, were added. The mixture was incubated for $30 \mathrm{~min}$ at $40^{\circ} \mathrm{C}$. Later, cleanup strategy through a SPE procedure was performed. For SPE, Oasis MAX mixed polymer phase cartridges were used. Aliquots of $3 \mathrm{~mL}$ of sample were applied to the cartridges previously conditioned with $1.5 \mathrm{~mL}$ of methanol and equilibrated with $1.5 \mathrm{~mL}$ of $0.02 \mathrm{M}$ formic acid, $\mathrm{pH} 4.5$. After sample charge, successive washings of interferences were performed using $1.5 \mathrm{~mL}$ of $\mathrm{NH}_{3} 2 \%$ (v/

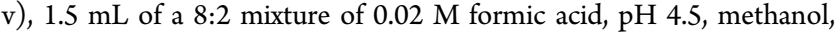
and $1.5 \mathrm{~mL}$ of hexane. PhytoPs and PhytoFs retained were eluted with $1.5 \mathrm{~mL}$ of a (70:29.4:0.6) hexane/ethanol/acetic acid mixture. Finally, the sample was concentrated with $\mathrm{N}_{2}$ at $40{ }^{\circ} \mathrm{C}$, and it was reconstituted in $100 \mu \mathrm{L}$ of mobile phase to its injection in the micro-HPLC-QTRAP system.

Analytical Characterization. The analytical parameters of sensitivity, linearity, matrix effect, accuracy, and precision were determined to validate the methodology used for PhytoP and PhytoF quantification in leaves of melon plants. Sensitivity was evaluated in terms of detection and quantification limits (LOD and LOQ), which were calculated by taking into account 3.3 and 10 times the signal-tonoise ratio, respectively. ${ }^{37}$ Linearity was evaluated using six PhytoP and PhytoF concentration levels for the internal standard calibration curve (three technical replicates at each concentration level), and this curve was measured under the optimal experimental conditions. The calibration equations were calculated by the least-squares linear regression method. Thus, linearity was determined from 4 to $512 \mathrm{pg}$ $\mu \mathrm{L}^{-1}$ of PhytoPs and PhytoFs injected in column. The standard solutions were prepared in $83 \%$ solvent A and $17 \%$ solvent B, the composition of which corresponds to the mobile phase at the initial stage of elution gradient.

In mass spectrometry, the analytical signal may be suppressed or exalted by the sample matrix; ${ }^{38}$ thus, internal calibration plots in the sample matrix were used to evaluate quantitatively the matrix effect. For this, PhytoP and PhytoF standards in perfectly known quantities were added to a homogeneous leaf sample. The PhytoP and PhytoF addition levels were $16,32,64,128$, and $256 \mathrm{pg} \mu \mathrm{L}^{-1}$. These spiked samples were processed with the extraction methodology abovedescribed and with three replicas for each level. Precision was estimated as relative standard deviation (RSD) considering intraday precision or repeatability and interday precision or reproducibility. Accuracy was expressed as recovery percent and was determined after the addition of PhytoP and PhytoF standards in quantities perfectly known to a homogeneous leaves of melon plants sample. The PhytoP and PhytoF addition levels were 32, 64, and $128 \mathrm{pg} \mu \mathrm{L}^{-1}$. These spiked samples were prepared with three replicas for each level and were processed during three different days.

Statistical Analyses. Analysis of variance was used to determine significant differences among data. Each statistical analysis was done using the software program INFOSTAT version 2012 (Universidad Nacional de Cordoba). The Fisher LSD test was used to compare means when the effects were found to be significant $(P<0.05)$.

\section{RESULTS AND DISCUSSION}

Phytop and Phytof Determination in Melon Leaves: Assay Validation. Eight PhytoPs and two PhytoFs were identified and quantified in leaves of melon plants for the first time. Their chemical structures and names, according to Taber's nomenclature system, ${ }^{39}$ are shown in Figure 2.

PhytoP and PhytoF measurements were performed following the chromatographic and mass spectrometry conditions abovementioned, in standard solutions as well as in real samples. A comparison between analyte retention times in solvent (mobile phase) and in samples was undertaken (Table 1); in this sense, the two types of retention times were not significantly different.

The PhytoPs identified in melon leaves were $\mathrm{F}_{1^{-}}, \mathrm{B}_{1^{-}}$, and $\mathrm{L}_{1^{-}}$PhytoPs, although the observed MRM transitions (Table 1) did not correspond to only one compound. In this way, the same MRM transition corresponds to four $\mathrm{F}_{1}$-PhytoP stereoisomers (ent-16-epi-16- $\mathrm{F}_{1 \mathrm{t}}$-PhytoP, ent-16- $\mathrm{F}_{1 \mathrm{t}}$-PhytoP, 9-epi-9- $\mathrm{F}_{1 \mathrm{t}}-\mathrm{Phy}$ toP, and $9-\mathrm{F}_{1 \mathrm{t}}$-PhytoP); however, in this case, these compounds 
<smiles>CC[C@H](O)/C=C/C1C(O)CC(O)C1CCCCCCCC(=O)O</smiles><smiles>CCC(O)/C=C/C1C(O)CC(O)C1CCCCCCCC(=O)O</smiles>

ent-16-epi-16-- $\mathrm{F}_{1+}$ PhytoP (1 PhytoP) ent-16-Fit PhytoP (2 PhytoP)<smiles>CCC1C(O)CC(O)C1/C=C/[C@@H](O)CCCCCCCC(=O)O</smiles>
9-epi-9- $\mathrm{F}_{1 \mathrm{t}}$ - PhytoP (3 PhytoP) 9-F $\mathrm{F}_{\text {lt }}$ PhytoP (4 PhytoP)<smiles>CCC(O)/C=C/C1=C(CCCCCCC(=O)O)C(=O)CC1</smiles><smiles>CC[C@H](O)/C=C/C1=C(CCCCCCC(=O)O)C2=C(CCC1=O)CC2</smiles>
ent-16-B $\mathrm{B}_{1-}$ PhytoP (5 PhytoP) 16-B Bt- $^{-}$PhytoP (6 PhytoP)<smiles>CCC1=C(/C=C/C(O)CCCCCC(=O)O)CCC1=O</smiles><smiles>CCC1=C(/C=C/C(O)CCCCC(=O)O)CCC1=O</smiles>

ent-9- $\mathrm{L}_{1 t}$ PhytoP (7 PhytoP)

9-L L PhytoP (8 PhytoP)

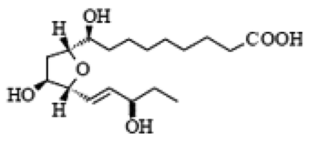<smiles>O=C(O)CCCCCCC[C@H](O)/C=C/[C@H]1OC[C@H](O)C[C@H]1O</smiles>

ent-16 (RS)-9-epi-ST- $\Delta{ }^{14}$-10-PhytoF ent-9 (RS)-12-epi-ST- $\Delta{ }^{10}-13-$ PhytoF

(1 PhytoF)

(2 PhytoF)

Figure 2. Chemical structures and names of PhytoPs and PhytoFs according to Taber. ${ }^{39}$

were separated using their different retention times. By contrast, for $\mathrm{B}_{1^{-}}$and $\mathrm{L}_{1}$-PhytoP stereoisomers, different retention times could not be obtained due to coelution of peaks. Thus, $16-\mathrm{B}_{1}-\mathrm{PhytoP}$ and ent-16- $\mathrm{B}_{1}$-PhytoP as well as 9$\mathrm{L}_{1}$-PhytoP and ent-9- $\mathrm{L}_{1}$-PhytoP were quantified as a sum of two par members. The chromatographic separation of the eight PhytoPs, two PhytoFs, and the internal standard was optimum and is shown in Figure 3. The different colors of the

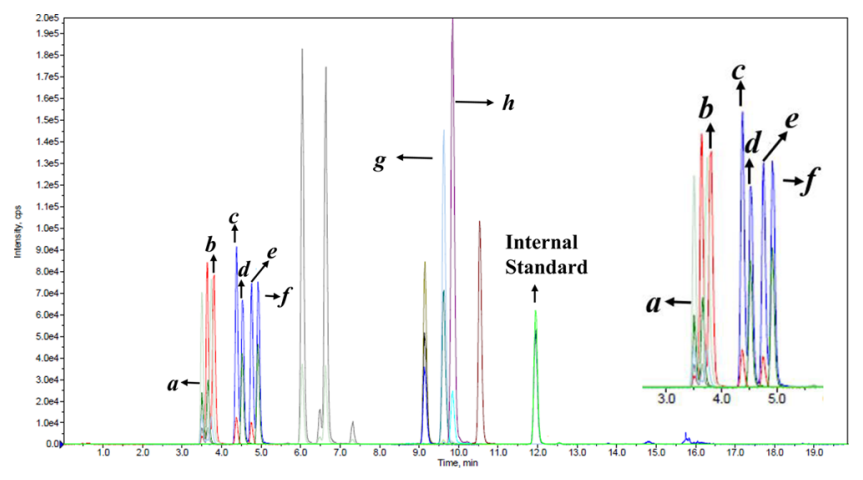

Figure 3. Typical chromatogram of PhytoPs (F series, dark blue peaks; L series, light blue peaks; B series, purple peaks) and PhytoFs (1 PhytoF, red peaks; 2 PhytoF, light green peaks). a, 2 PhytoF or ent9(RS)-12-epi-ST-10-13-PhytoF; $\boldsymbol{b}, 1$ PhytoF or ent-16(RS)-9-epi-ST14-10-PhytoF; $c$, 1 PhytoP or ent-16-epi-16-F1t- PhytoP; $d$, 3 PhytoP or 9-epi-9-F1t- PhytoP; $e, 2$ PhytoP or ent-16-F1t- PhytoP; $f$, 4 PhytoP or 9-F1t- PhytoP; $g, 5$ PhytoP or ent-16-B1t- PhytoP and 6 PhytoP or 16-B1t- PhytoP; $h, 7$ PhytoP or ent-9-L1t-PhytoP and 8 PhytoP or 9L1t-PhytoP.

chromatographic peaks in this figure represent the different series to which belong the quantified PhytoPs (F series, dark blue peaks; L series, light blue peaks; B series, purple peaks) and each PhytoF evaluated (1 PhytoF, red peaks; 2 PhytoF, light green peaks). On the other hand, the smaller peaks correspond to the identification MRM transitions of each analyte displayed as output of the MS/MS detector, which overlap as coelution peaks.

The PhytoPs identified and quantified in the study samples were also determined in other plant systems. In this sense, $\mathrm{F}_{1}$ PhytoPs were found in herb leaves ${ }^{9}$ and olives. ${ }^{15}$ Karg et al. ${ }^{40}$ have quantified $\mathrm{F}_{1}$-PhytoP and $\mathrm{B}_{1^{-}}$and $\mathrm{L}_{1}$-PhytoPs in edible vegetable oils as major and minor PhytoPs, respectively. With respect to PhytoFs, there is only one previous study that quantified the ent-16(RS)-13-epi-ST- $\Delta^{14}-9$-PhytoF in nuts and seeds. ${ }^{17}$ In the present work, the ent-16(RS)-9-epi-ST- $\Delta^{14}-10$ PhytoF and the ent-9(RS)-12-epi-ST- $\Delta^{10}-13$-PhytoF are identified and quantified in a plant system at the first time. The presence of ent-16(RS)-13-epi-ST- $\Delta^{14}$-9-PhytoF reported in nuts was also investigated, but this compound could not be detected in melon leaves.

The methodology used to quantify PhytoPs and PhytoFs in leaves of melon plants was validated in this plant system. Calibration plots of each analyte in a pure solvent were

Table 1. MRM Transitions and Retention Times (RT) for PhytoP and PhytoF Determinations in Leaves of Melon Plants by Micro-HPLC-QTRAP

\begin{tabular}{lcc}
\multicolumn{1}{c}{ analyte } & $\mathrm{Q}_{1}(m / z)$ & $\mathrm{Q}_{3}(m / z)$ \\
1 PhytoP & 327.200 & 283.200 \\
2 PhytoP & 327.200 & 283.200 \\
3 PhytoP & 327.200 & 283.200 \\
4 PhytoP & 327.200 & 283.200 \\
$5+6$ PhytoP & 307.000 & 235.000 \\
$7+8$ PhytoP & 307.200 & 185.000 \\
1 PhytoF & 343.200 & 209.000 \\
2 PhytoF & 343.200 & 237.100 \\
internal standard & 367.000 & 193.200
\end{tabular}

$\begin{array}{cc}\mathrm{RT}^{\mathrm{a}, b}(\mathrm{~min}) & \mathrm{RT}^{\mathrm{a}, c}(\mathrm{~min}) \\ 4.440 \pm 0.007 \mathrm{a} & 4.360 \pm 0.007 \mathrm{a} \\ 4.820 \pm 0.007 \mathrm{a} & 4.750 \pm 0.014 \mathrm{a} \\ 5.000 \pm 0.007 \mathrm{a} & 4.900 \pm 0.014 \mathrm{a} \\ 4.590 \pm 0.007 \mathrm{a} & 4.500 \pm 0.007 \mathrm{a} \\ 9.660 \pm 0.007 \mathrm{a} & 9.650 \pm 0.007 \mathrm{a} \\ 9.880 \pm 0.007 \mathrm{a} & 9.880 \pm 0.014 \mathrm{a} \\ 3.750 \pm 0.007 \mathrm{a} & 3.700 \pm 0.007 \mathrm{a} \\ 3.630 \pm 0.007 \mathrm{a} & 3.600 \pm 0.007 \mathrm{a} \\ 12.000 \pm 0.007 \mathrm{a} & 12.000 \pm 0.014 \mathrm{a}\end{array}$

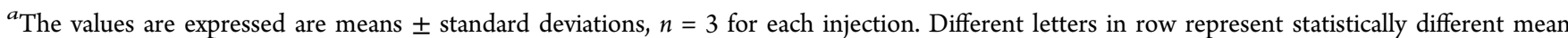
values $(P<0.05) .{ }^{b}$ Analyte retention time in solvent. ${ }^{c}$ Analyte retention time in matrix. 
performed to evaluate the linear range in the quantification process (Figure 4). In these assays, eight concentration levels in

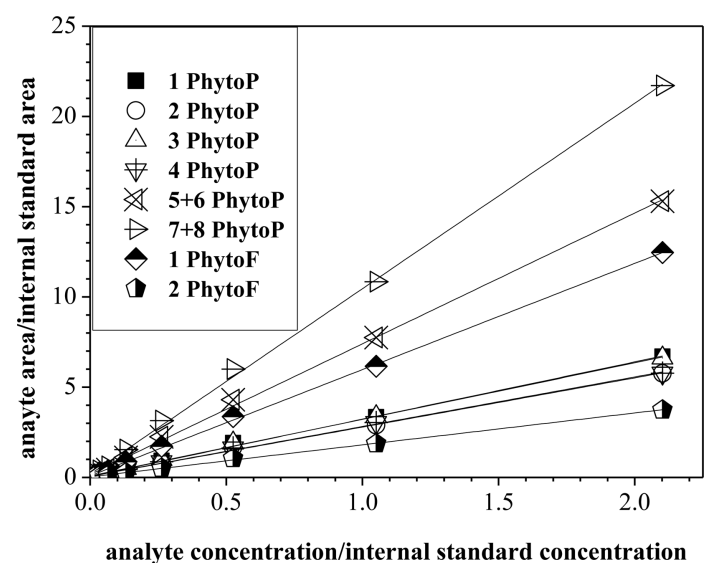

Figure 4. PhytoP and PhytoF calibration curves in solvent by microHPLC-QTRAP.

triplicate were used, and the linear regression equations are shown in Table 2. The detector response was linear between 0.40 and $51 \mathrm{pg} \mu \mathrm{L}^{-1}$ to the target compounds. An adequate ratio between concentrations and analytical signals was obtained for each PhytoP or PhytoF compound because the correlation coefficients were $>0.9950$ in all cases (Table 2 ).

LOD and LOQ values were calculated to evaluate the determinative capacity of the quantitative methodology for PhytoPs and PhytoFs used in the present work. The results (Table 2) show that these values markedly depend on the type of PhytoP analyzed. In this sense, the mean LOQ value was $0.052 \mathrm{pg} \mu \mathrm{L}^{-1}$ for $\mathrm{F}_{1}$-PhytoPs, whereas the same limit was 0.009 pg $\mu \mathrm{L}^{-1}$ for both $\mathrm{B}_{1^{-}}$and $\mathrm{L}_{1}$-PhytoPs. This difference in the limit magnitude order was informed previously by ColladoGonzález et al., ${ }^{41}$ but the methodology proposed in the present work presents LOD and LOQ values lower than that given by the mentioned authors. Finally in this work, figures for PhytoFs were calculated and reported for the first time.

On the other hand, the matrix effect on the analytical signal of PhytoP and PhytoF was evaluated by taking into account that in ESI-MS or ESI-MS/MS configurations the sample matrix can suppress or enhance the ionization process. ${ }^{38}$ This analysis was performed by comparison of PhytoP and PhytoF analytical signals in a solvent (mobile phase) and in a plant system. Calibration plots were constructed by adding known amounts of PhytoP and PhytoF standards to a homogeneous sample of melon leaves to reach different concentration levels (Figure 5). In this sense, the ratio between calibration slopes in

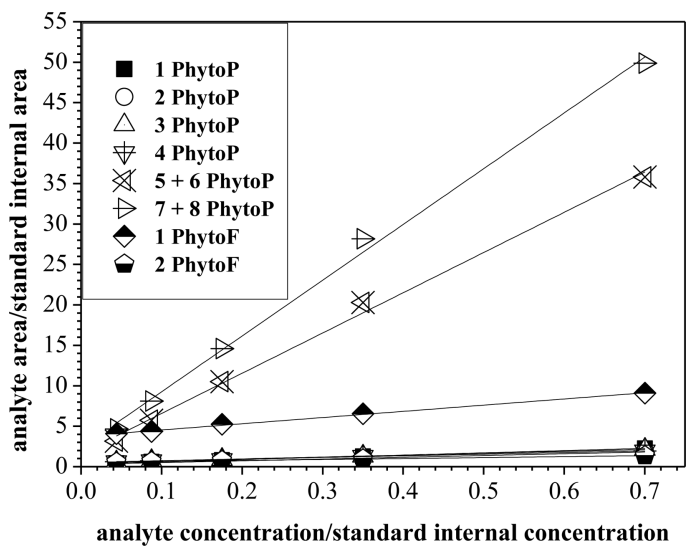

Figure 5. PhytoP and PhytoF calibration curves in sample matrix by micro-HPLC-QTRAP.

the mobile phase and in sample (Table 2) was calculated as the index of signal suppression or increased degree. The signal suppression between 5 and $25 \%$ was registered for $\mathrm{F}_{1}$-PhytoPs and ent-9(RS)-12-epi-ST- $\Delta^{10}$-13-PhytoF (2 PhytoF, Figure 2); on the contrary, a signal enhanced between 1 and 7 times was observed for $\mathrm{B}_{1^{-}}$and $\mathrm{L}_{1}$-PhytoP and ent-16(RS)-9-epi-ST- $\Delta^{14}$ 10-PhytoF (1 PhytoF, Figure 2), respectively.

Finally, precision and accuracy analytical parameters were evaluated. For this purpose, a homogeneous sample of the plant material was fortified with PhytoP and PhytoF standards in three intermediate levels in the linear range, and it was processed with the proposed methodology. Mean intraday precision was $3.7 \%$ with 1.2 and $5.3 \%$ as minimum and maximum values, respectively. Mean interday precision was $5.1 \%$ with 1.7 and $9.4 \%$ as minimum and maximum values, respectively. The precision degree obtained indicates that the quantification conditions reached in this work are reproducible for the PhytoP and PhytoF determination in leaves of melon plants because the RSD values were $<10 \%$. With respect to accuracy, recovery percentages were in the range between 81 and $106 \%$. Although these values are statistically different from $100 \%(P<0.0001)$, the results obtained are reliable because the recovery percentage is $>80 \%$ in all cases.

Monitoring of Phytoprostanes and Phytofurans as Oxidative Stress Biomarkers in Melon Plants. The optimized methodology was used to evaluate the PhytoP and PhytoF concentrations in dried leaves of melon plants. The PhytoP concentration range in these samples was from 110 to $1600 \mathrm{ng} / \mathrm{g}$. This range is in concordance with the corresponding range determined by Imbusch and Muller ${ }^{9}$ in herb plant leaves, which was 109-1146 ng/g. The PhytoF

Table 2. Figures of Merit in the PhytoP and PhytoF Quantification Process in Leaves of Melon Plants by Micro-HPLC-QTRAP

\begin{tabular}{|c|c|c|c|c|c|c|}
\hline analyte & $\mathrm{LOD}(\mathrm{pg} / \mu \mathrm{L})$ & LOQ $(\mathrm{pg} / \mu \mathrm{L})$ & regression line $e^{a}$ & $R^{2}$ & regression line $e^{b}$ & $R^{2}$ \\
\hline 1 PhytoP & 0.015 & 0.046 & $y=0.052+3.2 x$ & 0.9984 & $y=0.33+2.8 x$ & 0.9989 \\
\hline 2 PhytoP & 0.018 & 0.054 & $y=0.062+2.7 x$ & 0.9982 & $y=0.28+2.2 x$ & 0.9985 \\
\hline 3 PhytoP & 0.017 & 0.050 & $y=0.085+3.1 x$ & 0.9981 & $y=0.50+2.3 x$ & 0.9978 \\
\hline 4 PhytoP & 0.019 & 0.056 & $y=0.071+2.7 x$ & 0.9981 & $y=0.53+2.0 x$ & 0.9982 \\
\hline $5+6$ PhytoP & 0.0013 & 0.0078 & $y=0.15+7.2 x$ & 0.9986 & $y=1.6+50 x$ & 0.9953 \\
\hline $7+8$ PhytoP & 0.0034 & 0.010 & $y=0.17+10 x$ & 0.9989 & $y=2.4+69 x$ & 0.9961 \\
\hline 2 PhytoF & 0.0072 & 0.022 & $y=0.033+1.8 x$ & 0.9990 & $y=0.53+1.2 x$ & 0.9954 \\
\hline
\end{tabular}

${ }^{a}$ Regression line in solvent. ${ }^{b}$ Regression line in matrix. 
Table 3. PhytoP and PhytoF Levels in Leaves of Melon Plants: Evaluation of the Thermal Stress Effect

\begin{tabular}{|c|c|c|c|c|c|c|}
\hline \multirow[b]{3}{*}{ analyte } & \multicolumn{6}{|c|}{ biomarker level $^{a}\left(10^{2} \mathrm{ng} / \mathrm{g}\right)$} \\
\hline & \multicolumn{3}{|c|}{ assay 1: Sweet Ball cv. } & \multicolumn{3}{|c|}{ assay 2: Early Spring cv. } \\
\hline & control plants $^{b}$ & stressed plants $^{c}$ & $P$ value & control plants $^{b}$ & stressed plants ${ }^{c}$ & $P$ value \\
\hline 1 PhytoP & $6.9 \pm 1.3 \mathrm{a}$ & $12 \pm 3 b$ & 0.0030 & $5.3 \pm 1.1 \mathrm{a}$ & $9.5 \pm 1.6 b$ & 0.0002 \\
\hline 2 PhytoP & $5.9 \pm 1.2 \mathrm{a}$ & $12 \pm 2 b$ & 0.0001 & $5.1 \pm 0.9 \mathrm{a}$ & $9.5 \pm 2.4 b$ & 0.0011 \\
\hline 3 PhytoP & $7.5 \pm 1.6 \mathrm{a}$ & $13 \pm 3 b$ & 0.0020 & $5.9 \pm 0.7 \mathrm{a}$ & $9.5 \pm 1.8 b$ & 0.0001 \\
\hline 4 PhytoP & $7.1 \pm 1.9 \mathrm{a}$ & $16 \pm 4 b$ & 0.0010 & $7.1 \pm 0.4 \mathrm{a}$ & $11 \pm 3 b$ & 0.0007 \\
\hline $5+6$ PhytoP & $2.5 \pm 0.6 \mathrm{a}$ & $5.2 \pm 0.9 b$ & 0.0001 & $1.1 \pm 0.2 \mathrm{a}$ & $2.9 \pm 0.6 \mathrm{~b}$ & 0.0001 \\
\hline $7+8$ PhytoP & $2.2 \pm 0.5 \mathrm{a}$ & $4.6 \pm 1.1 \mathrm{~b}$ & 0.0008 & $1.7 \pm 0.4 \mathrm{a}$ & $3.8 \pm 0.9 b$ & 0.0005 \\
\hline 1 PhytoF & $25 \pm 4 a$ & $44 \pm 9 b$ & 0.0016 & $18 \pm 4 \mathrm{a}$ & $30 \pm 7 b$ & 0.0023 \\
\hline 2 PhytoF & $2.5 \pm 0.5 \mathrm{a}$ & $4.1 \pm 0.9 \mathrm{~b}$ & 0.0102 & $1.6 \pm 0.2 \mathrm{a}$ & $2.5 \pm 0.4 b$ & 0.0059 \\
\hline
\end{tabular}

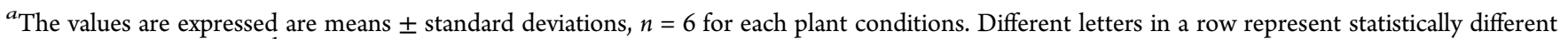
mean values $(P<0.05) .{ }^{b}$ Samples cultivated without cover and exposed to ambient temperature $\left(25-30{ }^{\circ} \mathrm{C}\right) .{ }^{c}$ Samples cultivated with cover and exposed to high temperatures $\left(35-45^{\circ} \mathrm{C}\right)$.

Table 4. PhytoP and PhytoF Levels in Leaves of Melon Plants: Evaluation of Bioactive Compound Spraying Effect in Samples with Plastic Cover or Stressed Samples

\begin{tabular}{|c|c|c|c|c|c|c|c|c|}
\hline \multirow[b]{3}{*}{ analyte } & \multicolumn{8}{|c|}{ biomarker level $^{a}\left(10^{2} \mathrm{ng} / \mathrm{g}\right)$} \\
\hline & \multicolumn{4}{|c|}{ assay 1: Sweet Ball cv. } & \multicolumn{4}{|c|}{ assay 2: Early Spring cv. } \\
\hline & control (water) & salicylic acid solution & yerba mate extract & $P$ value & control (water) & gallic acid solution & yerba mate extract & $P$ value \\
\hline 1 PhytoP & $12 \pm 4 a$ & $9.5 \pm 1.1 \mathrm{ab}$ & $7.6 \pm 1.2 b$ & 0.0122 & $9.5 \pm 1.6 \mathrm{a}$ & $6.8 \pm 1.4 \mathrm{~b}$ & $5.9 \pm 1.2 \mathrm{~b}$ & 0.0012 \\
\hline 2 PhytoP & $12 \pm 2 \mathrm{a}$ & $9 \pm 1 \mathrm{a}$ & $6.5 \pm 1.3 b$ & 0.0001 & $9.5 \pm 2.4 \mathrm{a}$ & $8.2 \pm 2.0 \mathrm{a}$ & $4.9 \pm 1.1 \mathrm{~b}$ & 0.0025 \\
\hline 3 PhytoP & $13 \pm 3 a$ & $11 \pm 1 \mathrm{a}$ & $7.8 \pm 16 b$ & 0.0013 & $9.5 \pm 1.8 \mathrm{a}$ & $8.0 \pm 2 \mathrm{a}$ & $5.2 \pm 1.1 \mathrm{~b}$ & 0.0001 \\
\hline 4 PhytoP & $16 \pm 4 a$ & $12 \pm 2 a$ & $8.7 \pm 1.9 b$ & 0.0024 & $11 \pm 3 a$ & $9.4 \pm 2.3 \mathrm{a}$ & $6.2 \pm 1.6 b$ & 0.0041 \\
\hline $5+6$ PhytoP & $5.2 \pm 0.9 \mathrm{a}$ & $3.2 \pm 0.5 b$ & $2.5 \pm 0.5 b$ & 0.0001 & $2.9 \pm 0.6 \mathrm{a}$ & $2.8 \pm 0.6 \mathrm{a}$ & $1.6 \pm 0.2 \mathrm{~b}$ & 0.0010 \\
\hline $7+8$ PhytoP & $4.6 \pm 1.1 \mathrm{a}$ & $3.4 \pm 0.6 b$ & $2.6 \pm 0.4 b$ & 0.0018 & $3.8 \pm 0.9 \mathrm{a}$ & $2.8 \pm 0.5 \mathrm{a}$ & $1.5 \pm 0.3 b$ & 0.0001 \\
\hline 1 PhytoF & $44 \pm 9 a$ & $35 \pm 3 a b$ & $32 \pm 6 b$ & 0.0252 & $30 \pm 7 a$ & $29 \pm 7 \mathrm{a}$ & $19 \pm 4 b$ & 0.0129 \\
\hline 2 PhytoF & $4.1 \pm 0.9 \mathrm{a}$ & $2.9 \pm 0.4 \mathrm{ab}$ & $2.5 \pm 0.5 b$ & 0.0122 & $2.5 \pm 0.4 \mathrm{a}$ & $1.9 \pm 0.5 \mathrm{a}$ & $1.5 \pm 3.2 b$ & 0.0038 \\
\hline
\end{tabular}

${ }^{a}$ The values are expressed are means \pm standard deviations, $n=6$ for each plant conditions. Different letters in row represent statistically different mean values $(P<0.05)$.

concentration range in leaves of melon plants was from 130 to $4400 \mathrm{ng} / \mathrm{g}$. PhytoFs were evaluated in a leaf matrix for the first time; therefore, the levels obtained in the present work cannot be compared with previous studies.

As mentioned earlier, the melon plants used in this work were grown under two different conditions: in open air conditions (control samples) and under cover conditions (thermally stressed samples). The stressed plants were grown covered with a plastic structure where they were exposed to high temperatures $\left(35-45^{\circ} \mathrm{C}\right)$, whereas the control plants were grown at regular temperatures for this crop $\left(25-30{ }^{\circ} \mathrm{C}\right)$ during the whole period. Besides, two different melon cultivars were studied, Sweet Ball in assay 1 and Early Spring in assay 2. As shown in Table 3, average PhytoP and PhytoF concentration levels of control and stressed samples were statistically different in both assays performed. The levels of the target compounds in plants exposed to thermal stress were from 1.6 to 2.2 times higher than the corresponding levels in control samples. Specifically, the compound in which the greatest variations were found was 9- $\mathrm{F}_{1}$-PhytoP (4 PhytoP, Figure 2), whereas the smallest variation was observed for ent9(RS)-12-epi-ST- $\Delta^{10}$-13-PhytoF (2 PhytoF, Figure 2).

Taking into account the described results, PhytoPs as well as PhytoFs can be considered potential oxidative stress biomarkers because their levels registered variations in plants grown under different stress conditions. Specifically, the oxidative stress produced as a consequence of thermal stress in melon plant was evaluated in this study. In this sense, high-temperature exposure during plant growth constitutes a potential stressful factor. Indeed, it has been established that the optimal temperature for melon crop growth is between 25 and $32{ }^{\circ} \mathrm{C}$. ${ }^{42}$ Furthermore, temperatures $<18{ }^{\circ} \mathrm{C}$ and $>35{ }^{\circ} \mathrm{C}$ begin to be a limiting factor for the mentioned biological function, and they are considered stressful. $^{43}$

Note that the PhytoP levels were evaluated in the present work for the first time to monitor the melon plant oxidative status after the thermal stress. In a previous study, the concentration of these oxidative stress biomarkers was quantified in response to the hydric stress in olives. ${ }^{15}$

With respect to the PhytoFs, their suitability as a potential oxidative stress biomarker was made evident in the present work for the first time because they were evaluated in a plant system after its exposure to a stress situation. There is only one previous study on PhytoFs that determined basal levels of these compounds in nuts and seeds. ${ }^{17}$

Specifically, the PhytoF level in stressed samples was higher than in control samples. These results can been explained considering that at temperatures $>35{ }^{\circ} \mathrm{C}$ stomatal closure is carried out in plants to avoid the excessive loss of water, similar to what occurs under hydric stress situation. ${ }^{44}$ The stomata are plant structures through which gas exchange takes place, and when they are closed the input of carbon dioxide and oxygen outlet are stopped during the light phase. In this situation, an oxygen accumulation is produced and this stimulates the PhytoF production. $^{13,16}$ 
Table 5. PhytoP and PhytoF Levels in Leaves of Melon Plants: Evaluation of Bioactive Compound Spraying Effect in Samples without Plastic Cover or Nonstressed Samples

\begin{tabular}{|c|c|c|c|c|c|c|c|c|}
\hline \multirow[b]{3}{*}{ analyte } & \multicolumn{8}{|c|}{ biomarker level $^{a}\left(10^{2} \mathrm{ng} / \mathrm{g}\right)$} \\
\hline & \multicolumn{4}{|c|}{ assay 1: Sweet Ball cv. } & \multicolumn{4}{|c|}{ assay 2: Early Spring cv. } \\
\hline & control (water) & salicylic acid solution & yerba mate extract & $P$ balue & control (water) & gallic acid solution & yerba mate extract & $P$ value \\
\hline 1 PhytoP & $6.9 \pm 1.3 \mathrm{a}$ & $6.3 \pm 0.7 \mathrm{a}$ & $5.4 \pm 1.0 \mathrm{a}$ & 0.1178 & $5.3 \pm 1.1 \mathrm{a}$ & $5.1 \pm 1.1 \mathrm{a}$ & $3.8 \pm 0.8 \mathrm{a}$ & 0.0550 \\
\hline 2 PhytoP & $5.9 \pm 1.2 \mathrm{a}$ & $5.7 \pm 0.5 \mathrm{a}$ & $4.7 \pm 0.9 \mathrm{a}$ & 0.0891 & $5.1 \pm 0.9 \mathrm{a}$ & $4.6 \pm 1.1 \mathrm{a}$ & $3.7 \pm 0.9 \mathrm{a}$ & 0.0655 \\
\hline 3 PhytoP & $7.5 \pm 1.6 \mathrm{a}$ & $6.9 \pm 0.6 \mathrm{a}$ & $6.2 \pm 0.8 \mathrm{a}$ & 0.1692 & $5.9 \pm 0.7 \mathrm{a}$ & $5.9 \pm 1.1 \mathrm{a}$ & $4.7 \pm 1.9 \mathrm{a}$ & 0.0805 \\
\hline 4 PhytoP & $7.1 \pm 1.9 \mathrm{a}$ & $7.1 \pm 0.1 \mathrm{a}$ & $6.7 \pm 1.3 \mathrm{a}$ & 0.3115 & $7.1 \pm 0.4 \mathrm{a}$ & $5.6 \pm 1.3 \mathrm{a}$ & $5.1 \pm 1.0 \mathrm{a}$ & 0.0601 \\
\hline $5+6$ PhytoP & $2.5 \pm 0.6 \mathrm{a}$ & $2.1 \pm 0.4 \mathrm{a}$ & $2.1 \pm 0.5 \mathrm{a}$ & 0.2192 & $1.1 \pm 0.2 \mathrm{a}$ & $1.0 \pm 0.1 \mathrm{a}$ & $0.9 \pm 0.1 \mathrm{a}$ & 0.2169 \\
\hline $7+8$ PhytoP & $2.2 \pm 0.5 \mathrm{a}$ & $2.1 \pm 0.2 \mathrm{a}$ & $2.1 \pm 0.3 \mathrm{a}$ & 0.8384 & $1.7 \pm 0.4 \mathrm{a}$ & $1.7 \pm 0.4 \mathrm{a}$ & $1.2 \pm 0.2 \mathrm{a}$ & 0.0608 \\
\hline 1 PhytoF & $25 \pm 4.4 \mathrm{a}$ & $26 \pm 5 a$ & $25 \pm 6 a$ & 0.7164 & $18 \pm 4 a$ & $17 \pm 4 a$ & $15 \pm 4 a$ & 0.4750 \\
\hline 2 PhytoF & $2.5 \pm 0.5 \mathrm{a}$ & $2.1 \pm 0.5 \mathrm{a}$ & $1.9 \pm 0.5 \mathrm{a}$ & 0.1994 & $1.6 \pm 0.2 \mathrm{a}$ & $1.4 \pm 0.2 \mathrm{a}$ & $1.3 \pm 0.3 \mathrm{a}$ & 0.1951 \\
\hline
\end{tabular}

Evaluation of the Antioxidants Application in Melon Plants. Different bioactive compounds with antioxidant properties were used to spray the plant leaves in control and stressed plants from both assays. This application was performed before exposure of the stressed plants to high temperatures under the cover material. The antioxidant compounds were sprayed on these plants to evaluate the ability of bioactive compounds to reduce or delay the oxidation process as a result of thermal stress. The stressed samples of each assay were divided into four groups, three with foliar application of antioxidants and one without application. The results obtained are shown in Table 4. In this sense, PhytoP and PhytoF levels from both assays corresponding to sample bioactive compounds added were lower than those of the stressed plant group without antioxidant application. The aqueous YM extract was the most effective antioxidant application because only in this plant group were the PhytoP and PhytoF levels statistically different when compared with the plants without antioxidant application (Table 4). This result may be explained by taking into account that YM has been identified as a mix of antioxidants, ${ }^{24-26}$ which can be more effective than the application of one pure antioxidant such as SA (assay 1) and GA (assay 2).

With respect to the variations of the stress biomarker contents, it was observed that PhytoP and PhytoF levels of the stressed samples sprayed with YM significantly decreased up to 2.5 times, in comparison with the stressed samples without antioxidants. Taking into account the YM applications to melon plants, results evidenced the protector effect of YM bioactive substances to prevent the oxidative reaction advance, whereas, concerning SA and GA application to stressed plants, the PhytoP and PhytoF levels decrease up to 1.5 times with respect to the stressed plants without antioxidants; however, statistical differences were not found. It is important to note that if the antioxidant addition leads to a decrease of the levels of oxidative stress biomarkers, this is new evidence that thermal stress in the early production of melon crop induces oxidative stress in the plant, which can be prevented by antioxidant application.

Note also that other studies have provided evidence of the antioxidant effect of $I$. paraguariensis after its application in foods. $^{28-30}$ This is the first report of using the aqueous YM extract to spray a plant system (melon plants) as a natural antioxidant source to reduce or alleviate thermal stress. In this sense, the protector effect of the YM antioxidants on lipid oxidation was verified because the decrease of PhytoP and
PhytoF levels was observed in the sprayed plants. Indeed, the most active antioxidant compounds in the assayed extracts are hydrophilic and, because of that, they would not be able to penetrate the lipid membranes. The protective ability of phenolic compounds against lipid membrane oxidation has previously been reported. The most hydrophilic flavonoids can interact with the membrane surface binding with the polar head groups of phospholipids, providing protection against external and internal oxidants. ${ }^{45}$ Further evidence has been reported concerning the insertion of rosmarinic acid in the lipid membrane. ${ }^{46}$ This compound is able to reside in the membrane close to the polar head groups of lipids in $1 \% / \mathrm{mol}$, and this fraction is efficiently able to prevent lipid oxidation. The interaction between lipid membranes and GA has also been reported. ${ }^{47} \mathrm{GA}$ action has been ascribed to a collapse of the water space between bilayers and to the hydrogen bond formation between the phenolic groups and hydrogen-bonding residues of the lipids.

On the other hand and as previously mentioned, the antioxidant application was also done in nonstressed samples (not covered) of both assays to evaluate a possible deleterious effect of these compounds in melon plant metabolism during its regular growing conditions. The results (Table 5) showed that the PhytoP and PhytoF levels were not statistically different between not covered plants groups with or without antioxidants in both assays. Those obtained results could be explained because there were no significant changes in the ambient temperature during the experiment time. This situation indicates that the bioactive compound addition does not affect the melon plant, and it was expected that the target compound levels were similar between nonstressed plant groups and could be considered a product of the ALA basal oxidation in the study system. As previously mentioned, the PhytoP and PhytoF levels quantified in samples with antioxidants were lower than the corresponding levels in samples without bioactive compounds. As a consequence, the application of antioxidants even under normal conditions of melon production in the summer could introduce improvements in yields because the plants would be protected against a possible stress.

Finally, to the best of our knowledge, this is the first study of PhytoP and PhytoF levels in leaves of melon plants after their exposure to thermal stress characteristic of the early-production conditions of this crop.

The methodology applied to quantify the compounds of our interest was based on micro-HPLC-QTRAP, which is the most recommended analytical technique to evaluate PhytoP and 
PhytoF concentrations. Also, the methodology was optimized to its use in plant system, and the results obtained with it are reliable according to the analytical parameter values found. Thus, it was possible to reach the unequivocal identification and quantification of six PhytoPs and two PhytoFs in leaves of melon plants.

PhytoP and PhytoF levels statistically different were found in leaves of thermally stressed melon plants compared with control plants. The target compound concentrations in stressed samples were up to 2.5 times higher than those in nonstressed samples. Thus, PhytoPs and PhytoFs represent relevant oxidative stress biomarkers in the system studied. It is important to note that the PhytoP level was related with thermal stress, and the PhytoF level as well can be considered as an oxidative stress biomarker.

Besides, the antioxidant capacity of different bioactive compounds to prevent oxidative stress was also studied. In this sense, the foliar spraying of an aqueous YM extract was most effective in decreasing production of PhytoPs and PhytoFs; perhaps it takes place by inducing the plant defense mechanism by intrinsic antioxidant system. This situation was verified using two different melon plant cultivars. The obtained results demonstrate that by using natural compounds that do not affect the plant structure and function it is possible to control the oxidative stress in adverse environmental conditions. This could lead increases in the melon crop yield even in stressful conditions and opens further research opportunities to evaluate plant resistance (and productivity) to abiotic stress and to reduce its effects using prevention alternative mechanisms such as antioxidant application.

\section{AUTHOR INFORMATION}

\section{Corresponding Authors}

*(C.V.) E-mail: Claire.vigor@umontpellier.fr.

*(M.A.N.) E-mail: manazar2004@yahoo.com, nazareno@unse. edu.ar.

\section{Funding}

We gratefully acknowledge the financial support received from Consejo Nacional de Investigaciones Científicas y Técnicas (CONICET), BEC.AR program, Universidad Nacional de Santiago del Estero, and INTA Santiago del Estero.

\section{Notes}

The authors declare no competing financial interest.

\section{ABBREVIATIONS USED}

ALA, $\alpha$-linolenic acid; BHT, butylated hydroxytoluene; cv., cultivar; ESI, electrospray ionization; $\mathrm{DPPH}^{\bullet}, 1,1$-diphenyl-2picrylhydrazyl radical; GA, gallic acid; LC-MS/MS, liquid chromatography coupled to tandem mass spectrometry; LOD, limit of detection; LOQ limit of quantification; MDA, malondialdehyde; QTRAP, triple-quadrupole combined to ion trap mass spectrometer; MRM, monitoring reaction mode; PhytoFs, phytofurans; PhytoPs, phytoprostanes; ROS, reactive oxygen species; RSD, relative standard deviation; SA, salicylic acid; SOD, superoxide dismutase; SPE, solid phase extraction; YM, yerba mate

\section{REFERENCES}

(1) FAO. The State of the World'S Land and Water Resources for Food and Agriculture (SOLAW) - Managing Systems atRrisk; Food and Agriculture Organization of the United Nations/Earthscan: Rome/ London, 2011; pp 9-12.
(2) Schmidhuber, J.; Tubiello, F. N. Global food security under climate change. Proc. Natl. Acad. Sci. U. S. A. 2007, 104, 19703-19708.

(3) Wang, W.; Vinocur, B.; Altman, A. Plant responses to drought; salinity; and extreme temperatures: towards genetic engineering for stress tolerance. Planta 2003, 218, 1-14.

(4) Hasanuzzaman, M.; Hossain, M. A.; Teixeira da Silva, J. A.; Fujita, M. Plant responses and tolerance to abiotic oxidative stress: antioxidant defenses is a key factor. In Crop Stress and Its Management: Perspectives and Strategies; Bandi, V., Shanker, A. K., Shanker, C., Mandapaka, M., Eds.; Springer: Berlin, 2012; pp 261-316.

(5) Gülen, H.; Çetinkaya, C.; Kadıŏlu, M.; Kesici, M.; Cansev, A.; Eriş, A. Peroxidase activity and lipid peroxidation in strawberry $($ Fragaria $\times$ ananassa) plants under low temperature. J. Biol. Environ. Sci. 2008, 6, 95-100.

(6) Ali, M.; Hahn, E.; Paek, K. Effects of temperature on oxidative stress defense systems, lipid peroxidation and lipoxygenase activity in Phalaenopsis. Plant Physiol. Biochem. 2005, 43, 213-223.

(7) Parchmann, S.; Mueller, M. J. Evidence for the formation of dinor isoprostanes E1 from $\alpha$-linolenic acid in plants. J. Biol. Chem. 1998, 273, 32650-32655.

(8) Jahn, U.; Galano, J. M.; Durand, T. A cautionary note on the correct structure assignment of phytoprostanes and the emergence of a new prostane ring system. Prostaglandins, Leukotrienes Essent. Fatty Acids 2010, 82, 83-86.

(9) Imbusch, R.; Mueller, M. J. Formation of isoprostane F2-like compounds (phytoprostanes F1) from $\alpha$-linolenic acid in plants. Free Radical Biol. Med. 2000, 28, 720-726.

(10) Barbosa, M.; Collado-Gonzalez, J.; Andrade, P. B.; Ferreres, F.; Valentão, P.; Galano, J. M.; Durand, T.; Gil-Izquierdo, A. Nonenzymatic $\alpha$-linolenic acid derivatives from the sea: macroalgae as novel sources of phytoprostanes. J. Agric. Food Chem. 2015, 63, 64666474.

(11) Arts, M.; Grun, C.; DeJong, R. L.; Voss, H. P.; Bast, A.; Mueller, M. J.; Haenen, G. R. M. M. Oxidative degradation of lipids during mashing. J. Agric. Food Chem. 2007, 55, 7010-7014.

(12) Marhuenda, J.; Medina, S.; Díaz-Castro, A.; MartínezHernández, P.; Arina, S.; Zafrilla, P.; Mulero, J.; Oger, C.; Galano, J. M.; Durand, T.; Ferreres, F.; Gil-Izquierdo, A. Dependency of phytoprostane fingerprints of must and wine on viticulture and enological processes. J. Agric. Food Chem. 2015, 63, 9022-9028.

(13) Carrasco-Del Amor, A. M.; Collado-Gonzalez, J.; Aguayo, E.; Guy, A.; Galano, J. M.; Durand, T.; Gil-Izquierdo, A. Phytoprostanes in almonds: identification, quantification, and impact of cultivar and type of cultivation. RSC Adv. 2015, 5, 51233-51241.

(14) Carrasco-Del Amor, A. M.; Aguayo, E.; Collado-Gonzalez, J.; Guy, A.; Galano, J. M.; Durand, T.; Gil-Izquierdo, A. Impact of packaging atmosphere, storage and processing conditions on the generation of phytoprostanes as quality processing compounds in almond kernels. Food Chem. 2016, 211, 869-875.

(15) Collado-Gonzalez, J.; Moriana, A.; Giron, I. F.; Corell, M.; Medina, S.; Durand, T.; Guy, A.; Galano, J. M.; Valero, E.; Garrigues, T.; Ferreres, F.; Moreno, F.; Torrecillas, A.; Gil-Izquierdo, A. The phytoprostane content in green table olives is influenced by Spanishstyle processing and regulated deficit irrigation. Food Sci.Technol. 2015, 64, 997-1003.

(16) Fessel, J. P.; Porter, N. A.; Moore, K. P.; Sheller, J. R. Discovery of lipid peroxidation products formed in vivo with a substituted tetrahydrofuran ring (isofurans) that are favored by increased oxygen tension. Proc. Natl. Acad. Sci. U. S. A. 2002, 99, 16713-16718.

(17) Cuyamendous, C.; Leung, K. S.; Durand, T.; Lee, J. C.Y.; Oger, C.; Galano, J. M. Synthesis and discovery of phytofurans: metabolites of $\alpha$-linolenic acid peroxidation. Chem. Commun. 2015, 51, 1569615699 .

(18) Bidabadi, S.; Mahmood, M.; Baninasab, B.; Ghobadi, C. Influence of salicylic acid on morphological and physiological responses of banana (Musa acuminata cv. 'Berangan', AAA) shoot tips to in vitro water stress induced by polyethylene glycol. Plant Omics J. 2012, 5, 33-39. 
(19) Arfan, M.; Athar, H. R.; Ashraf, M. Does exogenous application of salicylic acid through the rooting medium modulate growth and photosynthetic capacity in two differently adapted spring wheat cultivars under salt stress? J. Plant Physiol. 2007, 164, 685-694.

(20) Abdul Qados, A. M. S. Effects of salicylic acid on growth, yield and chemical contents of pepper (Capsicum annuum) plants grown under salt stress conditions. Int. J. Agric. Crop Sci. 2015, 8, 107-113.

(21) Kim, Y. J. Antimelanogenic and antioxidant properties of gallic acid. Biol. Pharm. Bull. 2007, 30, 1052-1055.

(22) Ozfidan-Konakci, C.; Yildiztugay, E.; Kucukoduk, M. Protective roles of exogenously applied gallic acid in Oryza sativa subjected to salt and osmotic stresses: effects on the total antioxidant capacity. Plant Growth Regul. 2015, 75, 219-234.

(23) Bastos, D. H. M.; Oliveira, D. M.; Matsumoto, R. L. T.; Carvalho, P. O.; Ribeiro, M. L. Yerba mate: pharmacological properties, research and biotechnology. Med. Aromat. Plant Sci. Biotechnol. 2007, 1, 37-46.

(24) Filip, R.; Lopez, P.; Giberti, G.; Coussio, J.; Ferraro, G. Phenolic compounds in seven South American Ilex species. Fitoterapia 2001, 72, 774-778.

(25) Bravo, L.; Goya, L.; Lecumberri, E. LC/MS characterization of phenolic constituents of mate (Ilex paraguariensis, St. Hil.) and its antioxidant activity compared to commonly consumed beverages. Food Res. Int. 2007, 40, 393-405.

(26) Valerga, J.; Reta, M.; Lanari, M. C. Polyphenol input to the antioxidant activity of yerba mate (Ilex paraguariensis) extracts. Food Sci.Tec. 2012, 45, 28-35.

(27) Miranda, D. D. C.; Arcari, D. P.; Pedrazzoli, J.; Carvalho, P. O.; Cerutti, S. M.; Bastos, D. H. M.; Ribeiro, M. L. Protective effects of mate tea (Ilex paraguariensis) on $\mathrm{H}_{2} \mathrm{O}_{2}$-induced DNA damage and DNA repair in mice. Mutagenesis 2008, 23, 261-265.

(28) Racanicci, A. M. C.; Danielsen, B.; Skibsted, L. H. Mate (Ilex paraguariensis) as a source of water extractable antioxidant for use in chicken meat. Eur. Food Res. Technol. 2008, 277, 255-260.

(29) De Campos, R. M. L.; Hierro, E.; Ordoñez, J. A.; Bertol, T. M.; Terra, N. N.; De la Hoz, L. Fatty acid and volatile compounds from salami manufactured with yerba mate (Ilex parguariensis) extract and pork back fat and meat from pigs fed on diets with partial replacement of maize with rice bran. Food Chem. 2007, 103, 1159-1167.

(30) Beal, P.; Faion, A. M.; Cichoski, A. J.; Cansian, R. L.; Valduga, A. T.; De Oliviera, D.; Valuduga, E. Oxidative stability of fermented Italian-type sausages using mate leaves (Ilex paraguariensis St. Hil) extract as natural antioxidant. Int. J. Food Sci. Nutr. 2011, 62, 703-710.

(31) Duppy, A.; Le Fauder, P.; Vigor, C.; Oger, C.; Galano, J. M.; Dray, C.; Lee, J. C.Y.; Valet, P.; Gladine, C.; Durand, T.; BertrandMichel, J. Simultaneous quantitative profiling of 20 isoprostanoids from omega- 3 and omega- 6 polyunsaturated fatty acids by LC-MS/MS in various biological samples. Anal. Chim. Acta 2016, 921, 46-58.

(32) El Fangour, S.; Guy, A.; Despres, V.; Vidal, J. P.; Rossi, J. C.; Durand, T. Total syntheses of the eight diastereoisomers of the synanti-syn phytoprostanes F1 types I and II. J. Org. Chem. 2004, 69, 2498-2503.

(33) El Fangour, S.; Guy, A.; Vidal, J. P.; Rossi, J. C.; Durand, T. A flexible synthesis of the phytoprostanes B1 type I and II. J. Org. Chem. 2005, 70, 989-997.

(34) Pinot, E.; Guy, A.; Fournial, A.; Balas, L.; Rossi, J. C.; Durand, $\mathrm{T}$. Total synthesis of the four enantiomerically pure diasteroisomers of the phytoprostanes E1 type II and of the 15-E2t-isoprostanes. J. Org. Chem. 2008, 73, 3063-3069.

(35) Anbinder, P. S.; Deladino, L.; Navarro, A. S.; Amalvy, J. I.; Martino, M. N. Yerba mate extract encapsulation with alginate and chitosan systems: interactions between active compound encapsulation polymers. J. Encapsulation Adsorpt. Sci. 2011, 1, 80-87.

(36) Leung, K. S.; Chen, X.; Zhong, W.; Yu, A. C. H.; Lee, C.Y. J. Microbubble-mediated sonoporation amplified lipid peroxidation of Jurkat cells. Chem. Phys. Lipids 2014, 180, 53-60.

(37) Winefordner, J. D.; Long, G. L. Limit of detection. A closer look at the IUPAC definition. Anal. Chem. 1983, 55, 712A-724A.
(38) Bonfiglio, R.; King, R. C.; Olah, T. V. The effects of sample preparation methods on the variability of the electrospray ionization response for model drug compounds. Rapid Commun. Mass Spectrom. 1999, 13, 1175-1185.

(39) Taber, D. F.; Morrow, J. D.; Roberts, L. J. A nomenclature system for the isoprostanes. Prostaglandins 1997, 53, 63-67.

(40) Karg, K.; Dirsch, A. V.; Vollmar, M.; Cracowski, J. L.; Laporte, F.; Mueller, J. M. Biologically active oxidized lipids (phytoprostanes) in the plant diet and parenteral lipid nutrition. Free Radical Res. 2007, $41,25-37$.

(41) Collado-González, J.; Medina, S.; Durand, T.; Guy, A.; Galano, J. M.; Torrecillas, A.; Ferreres, F.; Gil-Izquierdo, A. New UHPLC$\mathrm{QqQ}-\mathrm{MS} / \mathrm{MS}$ method for quantitative and qualitative determination of free phytoprostanes in foodstuffs of commercial olive and sunflower oils. Food Chem. 2015, 178, 212-220.

(42) Jouyban, Z.; Hasanzade, R.; Sharafi, S. Chilling stress in plants. Int. J. Agric. Crop Sci. 2013, 5, 2961-2968.

(43) Wahid, A.; Gelani, S.; Ashraf, M.; Foolad, M. R. Heat tolerance in plants: an overview. Environ. Exp. Bot. 2007, 61, 199-223.

(44) Agehara, S.; Leskovar, D. Characterizing concentration effects of exogenous abscisic acid on gas exchange, water relations, and growth of muskmelon seedlings during water stress and rehydration. J. Am. Soc. Hortic. Sci. 2012, 137, 400-410.

(45) Erlejman, A.; Verstraeten, S.; Fraga, C.; Oteiza, P. The interaction of flavonoids with membranes: potential determinant of flavonoids antioxidant effects. Free Radical Res. 2004, 38, 1311-1320.

(46) Fadel, O.; El Kirat, K.; Morandat, S. The natural antioxidant rosmarinic acid spontaneously penetrates membranes to inhibit lipid peroxidation in situ. Biochim. Biophys. Acta, Biomembr. 2011, 1808, 2973-2980.

(47) Salcedo, C.; Frías, M.; Cutro, A.; Nazareno, M.; Disalvo, E. Antiradical activity of gallic acid included in lipid interphases. Biochim. Biophys. Acta, Biomembr. 2014, 1838, 2656-2561. 